\title{
IMPROVING THE ABILITY TO ANALYZE SOCIAL PHENOMENON WITH THE INTERDISCIPLINARY APPROACH OF THE GROUP INVESTIGATION MODEL
}

Submitted:

16 September 2021

Accepted:

5 Desember 2021

Published:

31 Januari 2022

\author{
Ilmawati Fahmi Imron*1 \\ ilmawati@unpkediri.ac.id \\ PGSD, FKIP, UN PGRI Kediri \\ *Corresponding Author
}

\begin{abstract}
Based on the observation results of social studies learning materialon social phenomena at PGSD UN PGRI Kediri, it can be concluded that most students are less responsive to problems that occur in society in an interdiciplinary manner. This will reduce the meaning of learning social science. Based on some of these shortcomings then classroom action research (CAR) is carried out by applying an interdisciplinary approach and the learning Group Investigation model, because this learning model requires students to be more active in developing their attitudes and knowledge about social studies learning, especially social phenomena material that is in accordance with their respective abilities in constructing their own knowledge. This research design uses Classroom Action Research (CAR) with the stages of planning, implementing, observing and reflecting. The subject of this study were students of PGSD UN PGRI Kediri class 2B, odd semester of the 2019/2020 academic year. The data taken in this study are data from the results of investigation reports and learning outcomes data in the form of tests on the assessment sheet. The results obtained after applying an interdisciplinary approach with the Group Investigation model on the material of social phenomena, namely learning have been successful. It is evident in the results of student performance that there has been an increase from the first cycle, namely the average score is 74.4 and the second cycle the average score is 89.3. Then the student learning outcomes also experienced an increase in scores, namely from the first cycle with an average score of 79.5 and the second cycle average score of 94 .
\end{abstract}

Keywords: Social Studies, Interdisciplinary, Group Investigation, Social Phenomena

\section{INTRODUCTION}

The current paradigm shift in learning has brought improvements to the mindset of higher education in Indonesia. Higher education is currently directed at producing students who are competent in their fields to answer current and future needs. According to Suwartini, S. (2017, vol.4, no.1) explained that competent and skilled students will be the capital of extraordinary development of the country. Therefore, learning as a form of education implementation must be able to prepare student to be ready to face the challenges of the present and the future.

One of the shifts in mindset in the implementation of learning is that student are expected to have the ability to deal with various situations in society, because of the role of student as social control in society where student are control controllers or barometers 
if social problems occur as a result of social changes in society. So that student are expected to gain knowledge and skills so that when they return to society, student are able to solve social problems through learning experiences in lectures.

One of the learning experiences that can improve problem solving skills at the tertiary level is learning social studies. Social studies learning is learning that examines social issues with elements of the study in the context of events, facts and generalizations (Nurhasanah, A. 2016, vol. 2, no. 1). Social studies learning is an interdisciplinary science from several social science disciplines, namely history, economics, geography, sociology, anthropology, social psychology, and politics. Then the material studied in social studies learning is phenomena that occur in society, both past, present and future phenomena.

In this phenomenon, students are expected to be able to analyze a social phenomenon, make considerations in solving social phenomena, and finally be able to make the right decisions in solving these social phenomena. Because currently there are many problems or social phenomena that occur both in the surrounding community and in Indonesia. Therefore, good learning is learning that should be able to improve students' abilities in solving a problem, not only deepening theory but also having to balance it with practice (Sukardi, T, 2015, vol. 8, no. 1). This is in accordance with the objectives of social studies learning, namely (1) recognizing concepts related to people's lives and their environment, (2) having basic abilities for logical and critical thinking, curiosity, inquiry, problem solving, and skills in social life, (3) have a commitment and awareness of social and humanitarian values, and (4) have the ability to communicate, cooperate, and compete in a pluralistic society at local, national and global levels (Kemendikbud 2013: 2).

In this regard, observations and interviews related to social studies learning were carried out at several universities. Observations and interviews were conducted in the PGSD UN PGRI Kediri, STKIP Nganjuk, and STKIP Tulungagung study programs in order to obtain information about the attitudes and mindsets of students during social studies learning with social phenomena material. Then based on the results of observations and interviews, it was concluded that when studying social phenomena in social studies courses, many students were less responsive to problems that occurred in society. This is proven by the fact that many students are sleepy, daydreaming, and playing with their cell phones until they are confiscated by the lecturer. Then, based on interviews conducted with lecturers, it was found that most of the students were less interested in social phenomena because they considered the learning less interesting, felt less challenged, only listened and saw from the lecturer's powerpoint.

Based on some of the shortcomings of the learning process, it can be concluded that learning material for social phenomena in social studies courses is less attractive to students so that students feel bored, they do not understand the importance of learning a problem. Meanwhile, in everyday life, student must have skills in dealing with problems, both problems around them and even personal problems. This is supported by some data from student assignment scores which are still 52\% or below the KKM (70\%). 
Based on this, classroom action research was conducted by applying the Group Investigation (GI) learning model because this learning model requires student to be more active in developing their attitudes and knowledge about social studies learning, especially social phenomena material that is in accordance with their respective abilities in constructing their own knowledge. (Imron, Ilmawati Fahmi \& Kukuh Andri Aka, 2018:103). Cooperative interactions among peers will achieve the best results if done in small groups so that cooperative attitudes can last forever. In the learning model, the Group Investigation (GI) lecturer only acts as a facilitator and resource person during lectures. Lecturers only supervise the course of group investigations that occur, to see if they can manage their tasks, and help any difficulties they face in group interactions, including problems in performance on tasks related to learning (Slavin, 2011:217).

In addition, the advantages of the Group Investigation (GI) learning model are that the learning model is able to improve high-order thinking or High Order Thinking (HOT) students (Asyari, M., Al Muhdhar, MHI, \& Susilo, H, 2016). High Order Thinking (HOT) is an abstract ability that is in the cognitive domain of the taxonomy of educational targets which includes analysis, synthesis, and evaluation. If student have achieved higher-order thinking skills, then students have the ability to think critically, creatively, logically, and openly. If this already exists in student, then student will experience independence in the learning process. Learning independence is the basic capital for student to be responsible for solving various problems, both personal and social problems (Youngest, Kindergarten, Vilardi, M., Akbar, P., \& Bernard, M, 2019).

Based on some of the considerations above, a classroom action research was conducted which aims to determine the increase in the ability to analyze social phenomena with the interdisciplinary approach of the model group investigation in PGSD student entitled "Improving the Ability to Analyze Social Phenomena with the Interdisciplinary Approach of the Group Investigation (GI) Model". It is hoped that with this research, students' ability to analyze social phenomena with an interdisciplinary approach will increase and be able to train critical thinking skills to solve problems in society.

\section{METHODS}

The research design in this study was Classroom Action Research (CAR). There are four stages in classroom action research, namely 1) planning, 2) implementation; 3) observations made by observers; and 4) reflection. The results of the reflection are used to plan research in the next cycle. The indicator of the success of this research is seen from the increase in student learning outcomes related to the competence to analyze social phenomena.

\section{Research Subject}


The subject studied in this study were students of PGSD UN PGRI Kediri level two class B, even semester of the 2019/2020 academic year.

\section{Sources and Data Collection}

The data taken in this study are 1) data from the results of the investigation reports of each group contained in the assessment of student performance. The rubric for assessing student performance is in table 2 .

Table 2.

Rubric for Assessment of Student Performance

\begin{tabular}{|c|c|c|c|}
\hline $\begin{array}{l}\text { Aspects of } \\
\text { the } \\
\text { Assessment }\end{array}$ & Assessment & $\begin{array}{l}\text { Scale } \\
\text { of }\end{array}$ & Criteria for \\
\hline \multirow{12}{*}{$\begin{array}{c}\text { Observation } \\
\text { Report }\end{array}$} & \multirow{4}{*}{$\begin{array}{c}\text { Report } \\
\text { Systematic }\end{array}$} & 4 & $\begin{array}{l}\text { If the group reports on student performance are (1) in order, } \\
\text { (2) in accordance with the filling steps, and (3) according to } \\
\text { the procedure on the student performance sheet. }\end{array}$ \\
\hline & & 3 & $\begin{array}{l}\text { If one of the reporting systematic assessment criteria is not } \\
\text { met }\end{array}$ \\
\hline & & 2 & If two report systematic assessment criteria are not met \\
\hline & & 1 & If all report systematic assessment criteria are not met \\
\hline & \multirow{4}{*}{$\begin{array}{l}\text { Report } \\
\text { Contents }\end{array}$} & 4 & $\begin{array}{l}\text { If the group reports content on student performance (1) is } \\
\text { complete (from observations/interviews to attachments in the } \\
\text { form of photos), (2) interesting to read, (3) using effective } \\
\text { language using EYD rules. }\end{array}$ \\
\hline & & 3 & If one of the report content assessment criteria is not met \\
\hline & & 2 & If the two report content assessment criteria are not met \\
\hline & & 1 & If all report content assessment criteria are not met \\
\hline & \multirow{4}{*}{$\begin{array}{l}\text { Problem } \\
\text { Analysis }\end{array}$} & 4 & $\begin{array}{l}\text { If the results of the analysis on student performance are } \\
\text { detailed/detailed in analyzing the causes, impacts, follow-up } \\
\text { impacts, and solutions of several social phenomena and in } \\
\text { detail in analyzing them from the point of view of } 4 \text { subjects } \\
\text { (sociology, anthropology, social psychology, and law). }\end{array}$ \\
\hline & & 3 & $\begin{array}{l}\text { If the results of the analysis on student performance are } \\
\text { detailed enough/detailed enough in analyzing several social } \\
\text { phenomena (eg analyzing causes, impacts, further impacts, } \\
\text { but not providing a solution to the problem) and detailed } \\
\text { enough in analyzing them from the point of view of } 4 \text { subjects } \\
\text { (sociology, anthropology), social psychology, and law). }\end{array}$ \\
\hline & & 2 & $\begin{array}{l}\text { If the results of the analysis on student performance are less } \\
\text { detailed/less detailed in analyzing several social phenomena } \\
\text { (e.g. analyzing causes, impacts, further impacts, but not } \\
\text { providing a solution to the problem) and analyzing them from } \\
\text { the point of view of } 3 \text { subjects only. }\end{array}$ \\
\hline & & 1 & $\begin{array}{l}\text { If the results of the analysis on student performance are not } \\
\text { detailed in analyzing several social phenomena (only } \\
\text { analyzing the causes/impacts/continued impacts/solutions } \\
\text { only) and analyzing them from the point of view of less than } \\
3 \text { subjects. }\end{array}$ \\
\hline
\end{tabular}




\begin{tabular}{|c|c|c|c|}
\hline & & & \\
\hline & & 4 & $\begin{array}{l}\text { If in the presentation the students read the observation report } \\
\text { (1) systematically, (2) use good and correct Indonesian, and } \\
\text { (3) submit the report aloud. }\end{array}$ \\
\hline & Clarity of & 3 & If one of the presentation clarity assessment criteria is not met \\
\hline & & 2 & If the two presentation clarity assessment criteria are not met \\
\hline & & 1 & $\begin{array}{l}\text { If all report presentation clarity assessment criteria are not } \\
\text { met }\end{array}$ \\
\hline & & 4 & $\begin{array}{l}\text { If in the presentation, students can master } 4 \text { analyzes (cause, } \\
\text { impact, follow-up impact and solutions ) of several social } \\
\text { phenomena associated with } 4 \text { subjects (Sociology, } \\
\text { anthropology, social psychology, and law) }\end{array}$ \\
\hline Presentation & Knowledoe & 3 & $\begin{array}{l}\text { If in the presentation, students can master } 3 \text { analyzes (cause, } \\
\text { impact, sequelae and solutions) of several social phenomena } \\
\text { associated with } 4 \text { subjects (Sociology, anthropology, social } \\
\text { psychology, and law) }\end{array}$ \\
\hline & Knowleage & 2 & $\begin{array}{l}\text { If in the presentation, students can master } 2 \text { analyzes (cause, } \\
\text { impact, further impact and solution) of several social } \\
\text { phenomena that are connected with } 3 \text { subjects (Sociology, } \\
\text { anthropology, social psychology, and law) ) }\end{array}$ \\
\hline & & 1 & $\begin{array}{l}\text { If in a presentation, students can master } 1 \text { analysis (cause, } \\
\text { impact, follow-up impact and so lusion) of several social } \\
\text { phenomena associated with less than } 3 \text { subjects (Sociology, } \\
\text { anthropology, social psychology, and law) }\end{array}$ \\
\hline
\end{tabular}

ASSESSMENT SCORE $=\underline{\text { Score obtained }} \times 100$

Total score

Then 2) learning outcome data in the form of a test on an assessment sheet containing open-ended questions regarding material for prostitution, drug abuse (drugs), street children/punk children, and unemployment. There are 4 questions on the assessment sheet with the following criteria rubrics (1) Students are able to answer 3 questions with correct answers getting a score of 25/item questions, (2) Students are able to answer 2 questions with correct answers getting a score of 20/item questions, (3) Students are only able to answer 1 question with the correct answer getting a score of 15/item of question, and (4) Students who answer all questions but the answer is not correct get a score of 10/item of question. Just like the results of the performance assessment, the calculation of the description questions also uses the formula:

ASSESSMENT SCORE $=\underline{\text { Score obtained }} \times 100$

\section{Research Procedure}

\section{Total score}

This research lasted for 2 cycles, each cycle was carried out for 2 meetings/implementation and each cycle in this study consisted of four stages namely 1. Planning, 2. Implementation, 3. Observation, 4. Reflection (Arikunto, 2010). The CAR cycle flow will be described as Figure 1. 


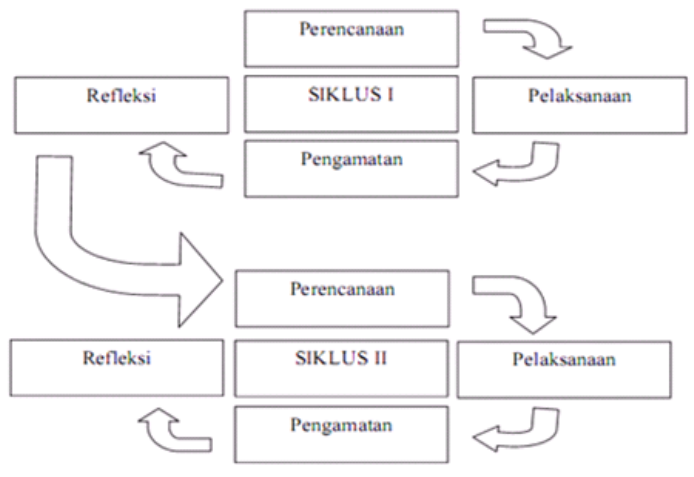

Figure 1. CAR

\section{Cycle I}

\section{Planning}

The steps taken by the researcher at this stage are to create a scenario for learning social phenomena material, in the form of a lecture implementation plan (RPP) adapted to the steps of the Group Investigation (GI) model, then prepares a module for group investigation because each group will have different problems, and prepares assessment instruments in the form of student performance and assessment sheets (tests).

\section{Implementation}

At this stage, the lecturer carries out learning activities according to the learning scenario made with the learning of Group Investigation (GI) model. The learning steps of Group Investigation (GI) in this research can be observed as shown in table 1 .

Table 1. Learning steps of Group Investigation (GI)

\begin{tabular}{|c|c|}
\hline Steps & Learning Activities (Lecturer) \\
\hline Group & $\begin{array}{ll}- & \text { Informing learning objectives } \\
\text { - } & \text { Creating an active and conducive classroom environment } \\
\text { - } & \text { Organizing students into several groups }\end{array}$ \\
\hline $\begin{array}{lll}\text { Organizing } & \text { students } & \text { to } \\
\text { learn } & & \end{array}$ & $\begin{array}{ll}\text { - } & \text { Dividing tasks to each group with different problems } \\
\text { - } & \text { Giving opportunities for each group to discuss } \\
\text { - } & \text { Giving opportunities for each group to investigate the given } \\
\text { problem } \\
\text { - Asking each group to make a report on the results of the } \\
\text { investigation }\end{array}$ \\
\hline Presentation & $\begin{array}{l}\text { - Asking group representatives to convey the results of their } \\
\text { investigations related to the problem } \\
\text { - Asking other groups to provide responses to the results of } \\
\text { their investigations }\end{array}$ \\
\hline Reflection & $\begin{array}{l}\text { - The lecturers and students together provide conclusions from } \\
\text { each problem and the results of the investigation from each } \\
\text { group }\end{array}$ \\
\hline
\end{tabular}

(Source: Aqib, 2015: 81) 


\section{Observation}

At this stage, observations are made during the learning process by observer, namely research assistant. The task of the observer is to help researchers to record all findings on the implementation of learning both in class and when conducting group investigations outside campus and the observer also helps collect student performance scores.

\section{Reflection}

At this stage the researcher and research assistant analyze the success of learning from learning and the data sources obtained from the results of student performance assessments and tests on the assessment sheet to determine the success of implementing the Group Investigation (GI) model in social phenomena. Furthermore, the results of the analysis will be used to determine improvements at the next meeting.

\section{Cycle II}

This cycle has the same stages as the first cycle, namely planning, implementation, observation and reflection. Findings of problems and improvements continue to be made in each cycle. After cycle II ends, this research will be stopped.

\section{RESULT}

\section{Student Performance Results}

The results of this study were obtained for two cycles. Each cycle consists of two meetings. The following is a description of the data on the results of student performance in this study.

Table 3. Student Performance Data

\begin{tabular}{|c|c|c|c|c|c|}
\hline Cycle & Meeting & $\begin{array}{c}\text { Average score } \\
\text { of student } \\
\text { performance }\end{array}$ & $\begin{array}{c}\text { Qualitative } \\
\text { value }\end{array}$ & $\begin{array}{c}\text { Score per } \\
\text { cycle }\end{array}$ & Description \\
\hline \multirow{2}{*}{ I } & Meeting 1 & 70.3 & Good & \multirow{2}{*}{74,4} & - \\
\hline & Meeting 2 & 78,5 & Good & & Improved \\
\hline \multirow{2}{*}{ II } & Meeting 1 & 86,3 & Good & \multirow{2}{*}{89,3} & Increased \\
\hline & Meeting 2 & 92,2 & Very good & & Increased \\
\hline
\end{tabular}

Description: the information column is said to be increased if the score of the meeting is higher than the score of the previous meeting

It shows an increase in student performance results in cycle II compared to cycle I. To illustrate the increase in student performance results regarding the ability to analyze social phenomena, it can be seen in the diagram below. 


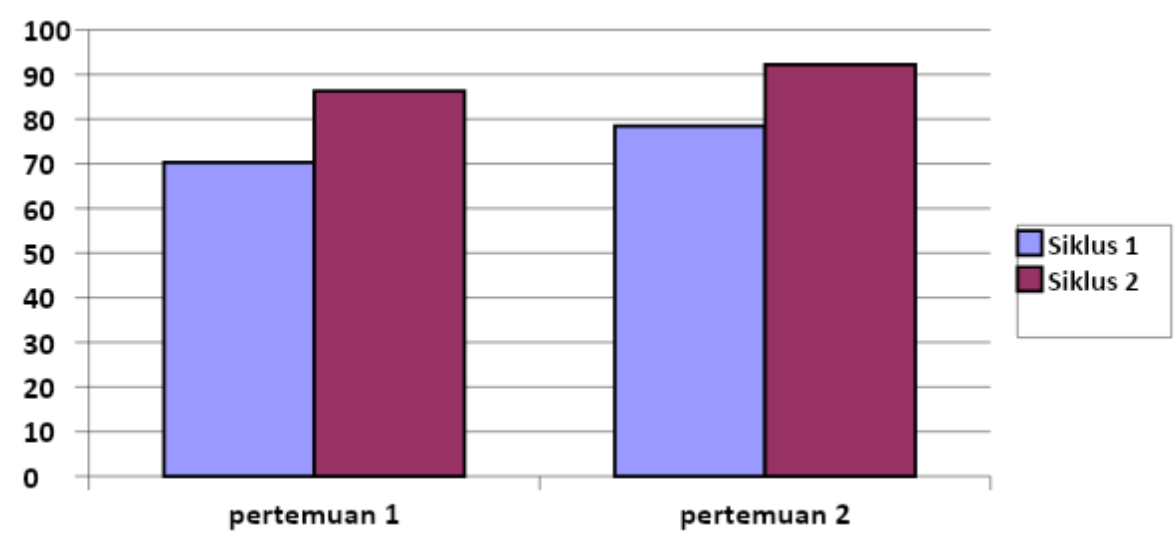

Diagram 1. Student Performance Results Data

\section{Student Learning Outcomes}

The following are student learning outcomes obtained from the assessment sheet work test.

Table 4. Learning Outcomes Data

\begin{tabular}{cccccc}
\hline \multirow{2}{*}{ Cycle } & Meeting & $\begin{array}{c}\text { Average score } \\
\text { of student } \\
\text { performance }\end{array}$ & $\begin{array}{c}\text { Qualitative } \\
\text { value }\end{array}$ & $\begin{array}{c}\text { Score per } \\
\text { cycle }\end{array}$ & Description \\
\hline \multirow{2}{*}{ I } & Meeting 1 & 79 & Good & 79.5 & - \\
\cline { 2 - 4 } Meeting 2 & 80 & Good & & Improved \\
\hline \multirow{2}{*}{ II } & Meeting 1 & 93 & Good & & Improved \\
\cline { 2 - 4 } & Meeting 2 & 95 & Very good & & Improved \\
\hline
\end{tabular}

Description: the information column is said to increase if the score of the meeting is higher than the score of the previous meeting.

Based on the table above, it can be seen that the score of student learning outcomes in cycle I reached a score of 79.5 and cycle II a score of 94, this shows an increase in student performance results in cycle II compared to Cycle I. To illustrate the improvement in student learning outcomes regarding the ability to analyze social phenomena, it can be seen in the diagram below. 


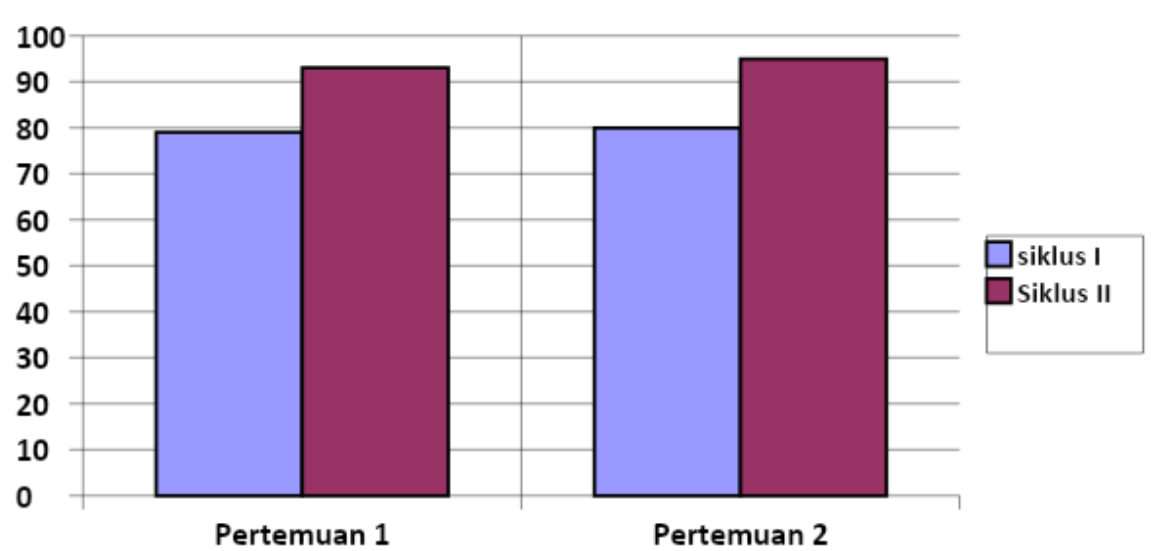

Diagram 2. Student Learning Outcomes Data

\section{DISCUSSION}

\section{In Cycle 1}

Planning

The steps taken by researcher at this stage are making a scenario for learning social phenomena material, in the form of a lecture implementation plan (RPP) adapted to the steps of the Group Investigation (GI) model, then prepare modules for group investigations because each group will have different problems, and prepare assessment instruments in the form of student performance and assessment sheets (tests).

Implementation

At this stage, the lecturer carries out learning activities according to the learning scenario made with the Group Investigation (GI) learning model. The Group Investigation steps based on Astuti, B. (2017, vol 4: no.3) on the material of social phenomena are as follows. (a) The learner divides the class into several groups, after the learner (lecturer) shows a video about social problems in Indonesia, the learner divides the students into several groups to complete the task from the student performance sheet given by the learner; (b) Learner explain the purpose of learning and give group assignments that must be done, namely the task for each group to make observations/observations or it can be done by interviewing several sources in certain areas that are the object of study of social phenomena material in order to dig up detailed information, which later results the observations or interviews are used as material for making reports on the results of observations as a result of carrying out tasks from the performance sheet; (c) Learner 
invite group leaders to choose the material on the task cooperatively in their groups. So in this activity, each group must choose a topic for studying social phenomena and then cooperatively each group carries out tasks according to the instructions of the Learner (Lecturer); (d) Each group discusses the task material cooperatively in their group, in this activity each group carries out observations and interviews. Then the results of the observations and interviews are written in the form of a report that is adapted to the format determined by the learner; (e) After completion, each group represented by the group leader or one of its members conveys the results of the discussion, namely after carrying out their duties, each group leader submits the results of observations in the area chosen as the object of the study topic; (f) Other groups can provide responses to the results of the discussion; (g) The learner provides a brief explanation (clarification) when a conceptual error occurs and provides a conclusion; and (h) conduct an evaluation in the form of giving a test.

\section{Observation}

At this stage, observations are made during the learning process by the observer, namely the research assistant. The task of the observer is to help researcher to record all findings on the implementation of learning both in class and when conducting group investigations outside campus and the observer also helps collect student performance scores. Wibawa, B. (2003: 2722) said that observation is the most important element in CAR research because the process is able to analyze and identify obstacles that cannot be explained in the test constraints.

Reflection

At this stage the researcher and research assistant analyze the success of learning from learning and the data sources obtained from the results of student performance assessments and tests on the assessment sheet to determine the success of implementing the Group Investigation (GI) model in social phenomena. Furthermore, the results of the analysis will be used to determine improvements at the next meeting. According to Widayati, A. (2008 vol.8, no.1) explained that reflection is a conclusion from several previous stages in order to know the extent of the implementation of the CAR. If there are still obstacles, then proceed to cycle 2 . 


\section{Cycle 2}

In cycle 2 the activities are the same as in cycle 1, namely planning by improving learning tools that are not satisfactory, then carrying out implementation, observation and reflection. Overall, in cycle 1, obstacles were found at the stages of "Creating an active and conducive classroom environment" and "Organizing Learner to learn". The drawback at the stage of "Creating an active and conducive classroom environment" is that in learning students are still complacent with previous learning, namely students only listen to the lecturer while looking at the lecturer's powerpoint. So that students still look passive and less enthusiastic about learning. The shortcomings at the stage of "Organizing Learner to Learn" namely when the lecturer divides tasks to each group with different problems, students are busy and often ask the lecturer, then when the lecturer gives each group the opportunity to discuss, many students do not understand the instructions from the lecturer., then when the lecturer gave each group the opportunity to investigate the given problem, many students were undisciplined because most of the groups took time to conduct investigations in the field so that some groups were not timely in collecting reports on the results of the investigation.

Then after reflecting on cycle 1 , cycle 2 was carried out with the same material and treatment, but taking into account the obstacles in cycle 1 so that in cycle 2 social phenomenon learning material for social phenomena ran smoothly. Several solutions were made to overcome these obstacles, namely the researcher provided a stimulus for better learning so that in cycle 2 , students were able to analyze social phenomena associated with several social science disciplines (interdisciplinary approach). The benefits obtained from this research are that students are able to think holistically about the problems that occur in society starting from the causes, impacts, further impacts, and the solutions offered from these problems which are seen from several perspectives from the social sciences Sudikan, SY (2015, vol. 2, no. 1).

The advantage of the group investigation (GI) model is that it increases student activity in the learning process. Observation of social phenomena in several disciplines requires students to be skilled in actually observing behavior in society, skilled in making reports, and skilled in presenting (Prasetyani, SD, Sajidan, S., \& Maridi, M, vol.4, no.2 , 2015). Learning will be more motivating if learning is active and "Hands on" which involves a lot of physical activity (Nicolls, 2004). Along with (De Jong \& Van Joolingen, 
1998) on discovery learning to be successful, learners must have a number of discovery skills. This learning model trains students to make observations in groups, thereby improving student skills and strengthening communication.

\section{CONCLUSION}

Based on the results of the study, it can be seen that during the two cycles of this classroom action research, the application of the model Group Investigation (GI) was successful in the Social Sciences course on social phenomena. It is evident in the results of student performance that there has been an increase from the first cycle, namely the average score is 74.4 and the second cycle the average score is 89.3 . Then the student learning outcomes also experienced an increase in scores, namely from the first cycle with an average score of 79.5 and an average score of 94 in the second cycle.

\section{ACKNOWLEDGMENTS}

The author would like to thank all parties involved in this research, namely the head of the study program PGSD for their permission to conduct this research as well as PGSD lecturers who helped the research process so that this research ran smoothly.

\section{REFERENCES}

Arikunto, Suharsimi. (2010). Prosedur Penelitian Suatu Pendekatan Praktik. Jakarta: Rineka Cipta

Astuti, B. (2017). Meningkatkan Motivasi dan Hasil Belajar IPS Siswa Kelas VI SD melalui Model Group Investigation. Mimbar Sekolah Dasar, 4(3), 264-271.

Asyari, M., Al Muhdhar, M. H. I., \& Susilo, H. (2016). Improving critical thinking skills through the integration of problembased learning and group investigation. International journal for lesson and learning studies.

Aqib, Zainal. (2015). Model-Model, Media, Dan Strategi Pembelajaran Kontekstual (Inovatif). Bandung: Yrama Widya

Bloom, Benjamin S., etc. (1956). Taxonomy of Educational Objectives: The Classification of Educational Goals. Handbook I Cognitive Domain. New York: Longmans, Green and Co. 
Bungsu, T. K., Vilardi, M., Akbar, P., \& Bernard, M. (2019). Pengaruh Kemandirian Belajar Terhadap Hasil Belajar Matematika Di Smkn 1 Cihampelas. Journal on Education, 1(2), 382-389.

De Jong, T., \& Van Joolingen, W. R. (1998). Scientific discovery learning with computer simulations of conceptual domains. Review of educational research, 68(2), 179-201.

Imron, Ilmawati \& Kukuh Andri Aka. (2018). Peningkatan Kemampuan Menganalisis Fenomena Sosial dengan Penerapan Model Problem Based Learning. Volume. 7, No.2, Agustus 2018. PEDAGOGIA: JURNAL PENDIDIKAN

Kemendikbud 2013. Kerangka Dasar Kurikulum 2013. Kementrian Pendidikan dan Kebudayaan Direktorat Jenderal Pendidikan Dasar. Jakarta

Kopertis. (2014). Modul Pelatihan Pengembangan Keterampilan Dasar Teknik Instruksional (Pekerti). Kopertis Wilayah VII

Nicolls, M. R. (2004). The clinical and biological relationship between Type II diabetes mellitus and Alzheimer's disease. Current Alzheimer Research, 1(1), 47-54.

Nurhasanah, A. (2016). Penggunaan metode simulasi dalam pembelajaran Keterampilan Literasi Informasi IPS bagi Mahasiswa PGSD. JPsd (Jurnal Pendidikan Sekolah Dasar), 2(1), 87-95.

Prasetyana, S. D., Sajidan, S., \& Maridi, M. (2015). Pengembangan Model

Pembelajaran Discovery Learning Yang Diintegrasikan Dengan Group Investigation Pada Materi Protista Kelas X SMA Negeri Karangpandan. Inkuiri, 4(2), 135-148.

Slavin, Robert E. (2011). Cooperative Learning Teori, Riset dan Praktik. Bandung: Remaja Rosdakarya.

Sudikan, S. Y. (2015). Pendekatan interdisipliner, multidisipliner, dan transdisipliner dalam studi sastra. Paramasastra, 2(1).

Sukardi, T. (2015). Pengembangan Strategi Konstruktivistik dalam Pembelajaran IPS untuk Meningkatkan Kepekaan Sosial Mahasiswa. Sosiohumanika, 8(1).

Suwartini, S. (2017). Pendidikan karakter dan pembangunan sumber daya manusia keberlanjutan. Trihayu: Jurnal Pendidikan Ke-SD-an, 4(1). 
Trianto. (2012). Mendesain Model Pembelajaran Inovatif Progresif: Konsep, Landasan, Dan Implementasinya Pada Kurikulum Tingkat Satuan Pendidikan (KTSP). Jakarta: Kencana prenada media group.

Wibawa, B. (2003). Penelitian Tindakan Kelas. Jakarta: Dirjen Dikdasmen, 2721-2572.

Widayati, A. (2008). Penelitian tindakan kelas. Jurnal Pendidikan Akuntansi Indonesia, $6(1)$. 